\begin{tabular}{c} 
Volume and Issues Obtainable at Center for Sustainability Research and Consultancy \\
Journal of Business and Social Review in Emerging Economies \\
ISSN: 2519-089X (E): 2519-0326 \\
Volume 6: No. 1, March 2020 \\
CSRᄃ \\
Journal homepage: www.publishing.globalcsrc.org/jbsee \\
\hline
\end{tabular}

\title{
A Political Discourse Analysis of the Speeches of President Obama and Prime
} Minister Gillani

${ }^{1}$ Tazanfal Tehseem, ${ }^{2}$ Sarwat Jabeen, ${ }^{3}$ Samia Naz

\author{
${ }^{1}$ Lecturer, Department of English, University of Sargodha, Pakistan. \\ ${ }^{2}$ Assistant Professor, Department of English, Bahauddin Zakariya University, Multan, Pakistan. \\ ${ }^{3}$ Course Coordinator, Quaid-e-Azam Academy for Educational Development, Punjab, Pakistan.
}

\begin{tabular}{l}
$\quad$ ARTICLE DETAILS \\
\hline History \\
Revised format: February 2020 \\
Available Online: March 2020 \\
\hline Keywords \\
$\begin{array}{l}\text { Discourse, ideology, political } \\
\text { speeches, socio-political } \\
\text { stance, transitivity }\end{array}$
\end{tabular}

JEL Classification:

D70, O1, O2

\begin{abstract}
This paper examines the discourse of the two political speeches made by the Pakistan Premier Syed Yousuf Raza Gilani and the US President Barack Obama after the elimination of Osama Bin Laden on May 3, 2011. The objective of this analysis is to discover and explicate how ideology is established and unveiled by the use of language. For the stated purpose, the framework of this study draws on Halliday's model of transitivity (Halliday and Matthiessen, 2004) through which we aim to investigate the transitivity choices employed by the individual speakers, the participant roles (Hasan, 1985 ) assigned to the enemy and the pronoun choices (Butt et. al., 2004) made by the two speakers in order to reveal a particular socio-political stance disseminated through the two speeches in two cultures: of the USA and Pakistan. The findings indicate that linguistic choices in transitivity play a fundamental role in conveying of implicit and dominant
\end{abstract}

(C) 2020 The authors, under a Creative Commons AttributionNonCommercial 4.0

Corresponding author's email address: sarwat.awan4@gmail.com

Recommended citation: Tehseem,T., Jabeen,S., \& Naz,S. (2020). A Political Discourse Analysis of the Speeches of President Obama and Prime Minister Gillani. Journal of Business and Social Review in Emerging Economies, 6(1), 209-228

DOI: $10.26710 /$ jbsee.v6i1.1040

\section{Introduction}

Towards the end of the previous century a view of language as an abstract system of rules detached from the context of its use dominated the linguistics which was much challenged by the forthcoming researchers that language is not only a system of rules detachable from the context of its use but most important in this regard is that how language functions within a particular context for the purposes of human communication. This is the view held by the functional linguists and is followed in the present study i.e. language can be made to perform several acts and language can be made to invoke several meanings as per the manipulation of the sources by the speakers of the language. This involves unveiling the purpose for which the speakers have used certain language and not the other way round. The present study aims to reach at the ideology promoted by the speakers through investigating the language employed by the individual speakers For this purpose, I plan to apply Hallidayan model of transitivity; a lexico-grammatical theory, which provides a basis for exploring how meanings are created and 
understood through the way language is used (Thompson, 2004), for a detailed analysis of different patterns in the selected texts to investigate the research aim which is the construction of ideological discourse using representational process of transitivity thus revealing the close relation between language and ideology.

\section{Background to the Study}

September 11, 2001 dawned upon United States of America as the worst day in history. New York and Washington DC were bombed allegedly by the Muslim militant organization Al-Qaeda. On October 7, 2011 President George W. Bush along with his allies waged the War on Terror which was intended to avenge the deaths caused as a result of those attacks and to ensure that all hostile elements that would further cause threat to US national security are searched and exterminated. Results of the war effected the entire region as Pakistan became target of proxy-based terrorists of Tehreek-e-Taliban which led to creation of a narrative that Pakistan is serving as a safe haven for terrorists which gave US a pretext of the doctrine of 'pre-emptive strikes' that served the publicly declared justification for the wars in Afghanistan and Iraq. In addition, the environment created by the 9/11 attacks facilitated the discussions of direct military conflicts. Therefore, on May 1, 2011 Operation Neptune Spear was carried out by US SEALs to eliminate Osama bin Laden who allegedly inhabited a compound in Abbotabad, Pakistan. Pakistan was concerned over violation of its territorial sovereignty. The Premier Gillani categorically stated in his speech that such violation in future will not be tolerated.

\section{Literature Review}

Political discourses offer a rewarding data for the analysts in terms of their ideological manipulations. Therefore, those have significantly been explored by applying the CDA framework (e.g. e.g. Fairclough 1992, 2000/02; Jones \& Collins 2006; Weiss \& Wodak 2007; Wodak \& Chilton. 2005; Wodak \& Meyer 2009 to quote a few). In addition, van Dijk (1993) elaborates the scope of the CDA that it domain includes investigations which examine the ways through which the politicians influence the common people in a society. $\mathrm{Pu}$ (2007) significantly contributes towards the pragmatic analysis of the then US President speech for portraying Americanism by adopting a political rhetoric. In doing so, he (ibid) finds that the President Bush uses persuading strategies to counter media reporting on portraying bad images of the US. In addition, Duran (2008) presents a very interesting study. In his contrastive analysis, he (ibid) explores acknowledgement strategies used by the two eminent political figures of the American politics. As van Dijk (1997) explains that personal feelings are well conveyed by the appropriate use of language so do the candidates concerned in their addresses to the American people. To support, Fairclough (1992) describes that the critical is employed to build relation between language and power.

Further, Fairclough (1989) points out that positioning of the speaker with the readers or the audience is revealed through the social reproduction. In an interview, Chomsky (1992) in regard to media and its use of language as a means to promote ideology referred to New York Times putting huge efforts in shaping the perceptions of the people belonging to an educated class. The political language, therefore, contains a complex web of connections between language, politics and ideology that promotes the vested interests of a group. Erikson and Tedin (2003) define ideology as "set of beliefs about the proper order of society and how it can be achieved." As far as connection between language, politics and ideology is concerned Pelinka (2007) claims that the scope of politics and political language is spread over everything that reflects power. Thus ideology is a phenomenon through which we can formulate various versions of an event which may be a semiotic event, biological, social, cultural or physical. It is not that language can be used ideologically, it is that the very use of language is ideological (Butt et al, 2004).As Hasan (1996) says that the powerful use language to manipulate the masses. However, it is a fact worth noticing that where on the one hand language can be used to defend or hide one reality at the same language offers the potential to be scrutinized (Hasan, 1996). What we build with language we can better understand by 'turning language back on itself' (Firth, 1957). Butt et al (2004) have analyzed the speeches of President Bush after 9/11 and British Lieutenant Colonel Tim Collins when they prepare their soldiers for war 
against Iraq in 2003. According to them (ibid), 'grammatical choices, as latent, unconscious patterns, approach this aim most directly in that they pass beneath our thresholds of censorship and monitoring' and they suggest that this is the responsibility of the discourse analysts to 'make overt the covert operations of war' which demands a 'specialized approach' and cannot be accomplished 'if left to popular observation'.

\section{Research Methodology and Data Collection}

The data for the present study which comprises the political speeches of Pakistani Prime Minister, Yousuf Raza Gilani and America's President, Barrack Obama have been taken from the newspapers. The reason for taking these political speeches is to analyze the stance and the ideology promoted by the leading members of the countries, one which carried out the operation and the other in which the operation is being carried out. Firstly the researchers have carried out the contextual analysis of the speeches. Then a strategy is presented which relates to the use of words in the speeches by both Obama and Gilani. We have also conducted an analysis of the pronoun choices in the speeches then the lexical repetition has been calculated. In the analysis, a comparison of the speeches is made which are in all 1367 and 2946 words long respectively for Obama and Pakistan Premier. The present study also looks at the ways in which Osama Bin Laden is portrayed in the speeches as a terrorist, enemy, etc. Linguistically, a text should not be taken as an ultimate goal rather a foil of embedded knowledge which can be explored, uncovered and highlighted in the line of interrogation (Caffarel et al., 2009). Hence, the goal of this paper is to uncover the choices made by the Obama, The contextual variables of the data have been described below:

Field: The speeches are concerned with the exposition of political discourse by Gilani's speech in Parliament and Obama's speech in live broadcast. These are related to Osama bin Laden's death and the reaction of both the politicians after his death.

Mode: The language is spoken in each case which is produced via oral channel and is intended to be processed by the ear. In Gilani's speech there is visual contact between the speaker and the reader as he delivered the speech in Parliament while Obama delivered the speech in live broadcast and hence there is no direct visual connection between him and his audience. In both the cases the communication is entirely one way.

Tenor: Both the speakers are addressing the audience of their respective countries but actually they are addressing the whole world. The speakers in both the cases have more power while the audience is completely passive.

\section{Research Questions}

i) What transitivity patterns have the speakers employed to construe ideological effects?

ii) What kinds of participant roles have been attributed to the enemy?

iii) Which pronoun choices are employed by the speakers to promote the implicit ideology?

\section{Construing Experience: The Grammar of Goings-on}

According to Halliday 'the world is experienced as a course of events or a series of going-ons' and this sequence of events is evaluated through the grammar of clause. The transitivity system construes the experience into a manageable set of process-types (Halliday \& Matthiessen, 2004). It is often said that it is complicated to track or make record of the experiences but grammar makes the distinction between those experiences of the outer world and of the inner consciousness. It divides the experiences into material and mental process-types respectively. 


\begin{tabular}{l|l|l|l|l}
$\begin{array}{l}\text { Various processes and associated details (Adapted from Thompson, 2004) } \\
\text { Causative } \\
\text { Participant }\end{array}$ & $\begin{array}{l}\text { Core } \\
\text { Participant 1 }\end{array}$ & Process & Core Participant 2 & $\begin{array}{l}\text { Other } \\
\text { Participants }\end{array}$ \\
\hline Initiator & Actor & Material & (Goal/Scope) & $\begin{array}{l}\text { Recipient/Client, } \\
\text { Attribute }\end{array}$ \\
\hline Inductor & Senser & Mental & Phenomenon/[projection] & \\
\hline Attributor & Carrier & $\begin{array}{l}\text { Relational: } \\
\text { attributive }\end{array}$ & Attribute & \\
\hline Assigner & Token & $\begin{array}{l}\text { Relational: } \\
\text { identifying }\end{array}$ & Value & \\
\hline Initiator & Behaver & Behavioral & (Range) & \\
\hline Initiator & $\begin{array}{l}\text { Sayer } \\
\text { Existent }\end{array}$ & $\begin{array}{l}\text { Verbal } \\
\text { Existential }\end{array}$ & Verbiage/[projection] & Receiver, Target
\end{tabular}

\section{Discussion on Transitivity Patterns}

In investigating the ideological presuppositions exploited by the individual speakers in their respective spoken discourses the transitivity analysis helps to configure out the field constructed by the speakers and what peculiar choices are employed in order to convey the particular stance to the broader world. A principal focus of the world view promoted by Obama and Gillani is the notion of enemy. Our main effort comprises to point out to the modus operandi in which they have pointed towards the enemy i.e. Osama Bin Laden as to whether they are mentioning him neutrally, or approaching positively or associating negative qualities to the enemy like the negative connotations of terrorist, extremist, murderer of thousands of innocent persons etc or referring to him through the use of nominalizations.

Obama's address gives the audience an outlook of the address of a 'triumphant' king. The peculiar manner and the characteristic style of his speech makes us believe that it is an announcement of some particular long-awaited victory. The characteristic difference between the two extracts we have with us in our data lies in this very quality that while Obama states his purpose very clearly in the beginning of his speech. In fact he starts with an announcement informing the whole American nation about the successful completion of the operation in Pakistan for killing Osama Bin Laden. In contrast to Obama's speech there is an explanatory manner being adopted in Gillani's speech. He is found to be giving explanations and justifications to the charges leveled against the sovereignty of Pakistan.

The predominant process-types in both the speeches take in the material processes followed by mental processes. The emotional process type is more dominant in Obama's speech while the cognition type processes are more frequent in Gillani's speech. Contrary to the expectations, no desideration processes are detected in both the speeches which indicate no personal wants or likes are directly projected by the speakers. Behavioral processes are in almost an equal ratio in both the speeches and same holds for the existential processes. There is a distinct difference in the case of verbal processes in both speeches. Verbal process type appeared to be much more affluent while investigating the transitivity patterns in Gillani's speech in comparison to Obama. Lastly, in case of relational processes there is again a noticeable contrast between the two. Relational attributive are much more opulent in Obama's speech while relational identifying are profusely found in Gillani's speech.

As stated above the most common process types in Obama's speech are the material processes which is to be expected as the speech is delivered soon after a happening that was of an immense importance in the world politics, i.e. killing of Osama Bin Laden. Material processes are those processes which encompass 
the physical actions, the processes of doing and happenings. A material clause is the one that elucidates a quantum of change in the sequence of events as happening via an input of energy (Halliday and Matthiessen, 2004). Keeping in view this description of the material clauses it becomes apparent that the majority of the clauses in Obama's speech involve processes of doing with some directed towards the positive actions of the United States while others projected towards the negative actions of the enemy. For instance, see the following example in table 1:

Table: 1

\begin{tabular}{l|l|l|l} 
Actor & Process: material & Goal & Others \\
\hline $\mathrm{We}$ & offered & our neighbors & a hand [circumstance] \\
\hline $\mathrm{We}$ & offered & the wounded & $\begin{array}{l}\text { our blood } \\
\text { [circumstance] }\end{array}$
\end{tabular}

In the example quoted from Obama's speech in table 1, it becomes evident that here 'we' refers either to the people of the United States or the US military, whoever it be, anyhow the point of importance is that this 'we' is involved in an action that is quite positive like 'offered our neighbors a hand' and 'offered the wounded our blood' which gives the impression of a highly civilized and helping nation. This implies that the Americans assisted their brethren in a moment of strife that was inflicted upon them from outside.

Consider another example given below:

Table: 2

\begin{tabular}{l|l|l|l} 
Actor & Process: material & Goal & Circumstance \\
\hline & protect & & our nation \\
\hline those & bring & & \\
\hline who & committed & this vicious attack & to justice
\end{tabular}

This stance of projecting the American's image as the protectors, defenders, and benefactors is promoted against the others' image as that of the one who's involved in negative activities which include attacking other nations and killing their citizens. In other words, what the Americans do is 'just' and what the others do is 'unjust' and the Americans actions are to be considered a response in result of the stimulus being the 'vicious attack'.

Likewise, there are numerous examples of this kind in our data. In most of the cases the enemy is projected as involved in physical actions that cause destruction and havoc for innocent people as can be observed in table 2. Similarly, in the example quoted below it is evident that US was forced to wage war against Al-Qaeda in order to protect her citizens, friends and allies.

We [senser] quickly learned [pr: mental, cognition] that the 9/11 attacks [goal] were carried out [pr: material] by Al-Qaeda - an organization [actor] headed [pr: rel. attributive] by Osama bin Laden [carrier] which had openly declared [pr: mental, cognition] war on the United States [phenomenon] and was committed [pr: mental, emotion] to killing [pr: material] innocents [goal] in our country and around the globe [circumstance: location]. And so we [actor] went [pr: material] to war [circumstance: extent] against Al-Qaeda [goal] to protect our citizens, our friends, and our allies [beneficiary].

Again in the end of Obama's speech it is observed that he concludes his speech by saying that 'we [actor] can do [pr: material] these things [goal] not just because of wealth or power, but because of who we are [pr: rel. attributive]: one nation, under God, indivisible, with liberty and justice for all.' 
Hence, it is found that almost all the material clauses in which enemy is found are indicating towards the negatively valued actions, which are often concrete and physical (kill, committed) and this killing involves other people which implies their actions are not limited to themselves but produce an undesirable effect on other's lives.

Moving on to the next dominant process-type in Obama's speech the researchers arrive at the mental processes. Amongst the mental processes the greater part is occupied by the cognition processes with next being the emotion process-type and afterwards comes the perception type with no desideration processtype. The high amount of mental cognition processes acknowledges the speaker being engrossed in thinking, deciding or recognition. For instance in the following example

Table: 3

\begin{tabular}{l|l|l|l} 
Senser & $\begin{array}{l}\text { Process: } \text { mental } \\
\text { (cognition })\end{array}$ & Phenomenon & Others \\
\hline By all & should be welcomed & his demise & $\begin{array}{l}\text { in peace and human } \\
\text { dignity }\end{array}$ \\
\hline Who & believe & & \\
\hline The American people & did not choose & this fight & \\
\hline So Americans & understand & the costs of war & \\
\hline I & know & $\begin{array}{l}\text { back to the sense of } \\
\text { unity that prevailed }\end{array}$ & on
\end{tabular}

All the above cited examples in table 3 show the mental processes of cognition in Obama's speech revealing the speaker as involved in various processes of thinking, understanding, believing, etc. The next proportion in Obama's speech forms the emotional processes showing solidarity with the audience as is witnessed in table 4. Obama has time and again made use of the emotional strategies in order to bring a sense of unity amongst the audience i.e. the American nation.

Table: 4

\begin{tabular}{l|l|l|l} 
Senser & $\begin{array}{l}\text { Process: } \text { mental } \\
\text { (emotion) }\end{array}$ & Phenomenon & Others \\
\hline American people & came together & our ties to each other & \\
\hline We & reaffirmed & $\begin{array}{l}\text { to avoid civilian } \\
\text { casualties }\end{array}$ & $\begin{array}{l}\text { the satisfaction of but tonight } \\
\text { their work and the } \\
\text { result of their pursuit } \\
\text { of justice }\end{array}$
\end{tabular}

The next prominent category in Obama's speech is the category of verbal processes. Verbal processes comprise the instances of saying, telling, reporting. In the present address Obama is reporting to his nation about the killing of their biggest enemy. Obama is addressing to his nation that after years of tireless 
effort they have been successful in the killing of Bin Laden. Table 5 below details some of the examples of this process-type from our data.

Table: 5

\begin{tabular}{l|l|l|l} 
Sayer & Process: verbal & Receiver & Verbiage \\
\hline I & can report & $\begin{array}{l}\text { to the American } \\
\text { people }\end{array}$ & war \\
\hline Osama Bin Laden & openly declared & on a possible lead to \\
I & was briefed & Pin Laden \\
\hline I & called & $\begin{array}{l}\text { countless intelligence } \\
\text { and counterterrorism } \\
\text { professionals }\end{array}$ &
\end{tabular}

In the case of Obama's speech verbal processes are manifested mainly to report 'heroic' events of Obama himself e.g. 'I can report to the American people', his military or the intelligence forces e.g. 'We give thanks to the countless intelligence and counterterrorism professionals', while some other as reporting on the negative declarations made by the enemy i.e. Osama Bin Laden e.g. 'Osama Bin Laden openly declared war'. For reference see table 5.

The last process-type which is witnessed in Obama's address are the relational attributive processes. Obama has employed this process-type in order to attribute the character traits to Osama Bin Laden which in all the instances constitute the negative characteristics. See table 6 for how President Obama introduces Osama Bin Laden in his address:

Table: 6

\begin{tabular}{l|l|l|l} 
Carrier & $\begin{array}{l}\text { Process: Relational } \\
\text { Attributive }\end{array}$ & Attribute & Others \\
\hline Osama Bin Laden & who's & $\begin{array}{l}\text { the leader of Al- } \\
\text { Qaeda } \\
\text { and a terrorist }\end{array}$ & $\begin{array}{l}\text { responsible for the } \\
\text { murder of thousands } \\
\text { of innocent men, } \\
\text { women and children } \\
\text { [circumstance: } \\
\text { matter] }\end{array}$
\end{tabular}

Another significant use of the relational attributive processes is where Obama identifies his nation and his own self with the positive character traits. See table 7 below. 
Table: 7

\begin{tabular}{l|l|l|l} 
Carrier & $\begin{array}{l}\text { Process: relational } \\
\text { attributive }\end{array}$ & Attribute & Others \\
\hline $\mathrm{We}$ & were & $\begin{array}{l}\text { what race or } \\
\text { ethnicity }\end{array}$ & $\begin{array}{l}\text { as one American } \\
\text { family }\end{array}$ \\
\hline $\mathrm{We}$ & were united & a mass murderer & of Muslims
\end{tabular}

Moving to Gillani's speech we find that the dominant process-type is the same as in the Obama's speech i.e. materials process-type. Gillani's address makes use of the material processes to represent the events in which Pakistan as a nation had been involved since the last many years. He is in a manner giving answers to the charges leveled against the Pakistan Army, ISI for being negligent in their security. See table 8 for examples of material process types from Gillani's address.

Table: 8

\begin{tabular}{l|l|l|l} 
Actor & Process: material & Goal & Others \\
\hline No other nation & met & so many challenges & $\begin{array}{l}\text { Successfully } \\
\text { [circumstance: } \\
\text { quality] }\end{array}$ \\
\hline We & $\begin{array}{l}\text { have continued } \\
\text { to suffer }\end{array}$ & from its effects &
\end{tabular}

Secondly, the material processes are seen to be made use of while giving an account of the activities of Al-Qaeda which are primarily destructive involving the killings of large numbers of Pakistanis along with huge scores from other countries. For a similar description and portrayal of the enemy in Obama's address see the table $5,6,7$.

Table: 9

\begin{tabular}{ll|l|l|l} 
Actor & & Process: material & Goal & Others \\
\hline $\begin{array}{l}\text { Osama Bin Laden } \\
\text { who }\end{array}$ & $\begin{array}{l}\text { elimination } \\
\text { launched } \\
\text { is indeed justice done }\end{array}$ & $\begin{array}{l}\text { waves after waves of } \\
\text { terrorists' attacks }\end{array}$ & $\begin{array}{l}\text { against innocent } \\
\text { Pakistanis }\end{array}$
\end{tabular}

Another aspect of the material processes in Gillani's address is focusing on the activities of Pakistan Army which involve efforts to eliminate terrorism, for examples see table 10. However, a similar description of American military and the intelligence forces can be seen in table 5. 
Table: 10

\begin{tabular}{l|l|l|l} 
Actor & Process: material & Goal & Others \\
\hline & to eliminate & terrorism & $\begin{array}{l}\text { from our sacred land } \\
\text { [circumstance: } \\
\text { location] }\end{array}$
\end{tabular}

Similarly, later he extends his arguments implying that Pakistanis have always been vigilant and there is no need of foreign invasions in order to eliminate terrorism from its land. For examples from our data see table 11.

Table: 11

\begin{tabular}{l|l|l|l} 
Actor & Process: material & Goal & Others \\
\hline By anyone & to be used & its soil & $\begin{array}{l}\text { for terrorism } \\
\text { [circumstance: } \\
\text { purpose] }\end{array}$
\end{tabular}

The important issue concerning Osama's hideout in Abbottabad is also addressed through material process-type that it is not right to blame Pakistan's forces only for the negligence because at the same time he was constantly been tracked by the intelligence of other countries including the United States.

Table: 12

\begin{tabular}{l|l|l|l} 
Actor & Process: material & Goal & Others \\
\hline $\begin{array}{l}\text { The Al Qaeda chief } \\
\text { along with other Al } \\
\text { Qaeda operators }\end{array}$ & $\begin{array}{l}\text { had managed } \\
\text { to elude } \\
\text { agencies }\end{array}$ & $\begin{array}{l}\text { for a long time } \\
\text { [circumstance: time] }\end{array}$ \\
\hline $\begin{array}{l}\text { Not only by the ISI } \\
\text { but also by other } \\
\text { intelligence agencies }\end{array}$ & was being tracked & he & $\begin{array}{l}\text { constantly } \\
\text { [circumstance: } \\
\text { quality] }\end{array}$
\end{tabular}

The next predominant category in Gillani's speech comprises the mental processes of cognition. Mental processes in Gillani's speech are seen engaged in reflecting the beliefs of the Pakistani nation and to reflect the determination of Pakistan Army, for instance as given in the Table 13:

Table: 13

\begin{tabular}{l|l|l|l} 
Senser & $\begin{array}{l}\text { Process: } \text { mental } \\
\text { (cognition) }\end{array}$ & Phenomenon & Others \\
\hline Pakistan & believes & $\begin{array}{l}\text { in democracy and } \\
\text { pluralism }\end{array}$ & \\
\hline Pakistan & $\begin{array}{l}\text { will not relent } \\
\text { is determined }\end{array}$ & in this national cause &
\end{tabular}

A point of importance is the fact that none of the mental processes of cognition are put to reflect the enemy's beliefs and stance which implies that the enemy is not given the right to speak. On the other hand the audience is introduced with the enemy by the speakers promoting their own specific viewpoints. See table 6 for how Obama introduces the enemy i.e. Osama Bin Laden and table 7 and 9 for the kind of activities in which Osama Bin Laden and his fellow terrorists are involved. 
The next dominant process-type in Gillani's address are found to be the verbal processes. Verbal processes are involved mainly in conveying the information about various important facts and clarifying the doubts about the image of Pakistan that prevail in the wider world, for instance see the examples in table 14.

Table: 14

\begin{tabular}{l|l|l|l} 
Sayer & Process: verbal & Receiver & Others \\
\hline $\mathrm{We}$ & did not invite & Osama Bin Laden & $\begin{array}{l}\text { to Pakistan or even to } \\
\text { Afghanistan } \\
\text { [circumstance: } \\
\text { location] }\end{array}$ \\
\hline & to ask & $\begin{array}{l}\text { who was Osama bin } \\
\text { Laden and what did } \\
\text { he personify } \\
\text { [verbiage] }\end{array}$
\end{tabular}

In fact 'we [sayer] did not invite [pr: verbal] Al Qaeda [receiver] to Pakistan [circumstance: location]' is repeated twice in Gillani's address which signifies that the Pakistani forces aren't responsible for Osama's hideout in the mountains of Abbottabad. Similarly, time and again we see Gillani employing the verbal processes to dismiss the charges against Pakistan Army and the ISI, for instance see table 15.

Table: 15

\begin{tabular}{l|l|l|l} 
Sayer & Process: verbal & Receiver & Others \\
\hline For anyone & to blame & $\begin{array}{l}\text { or State institutions of } \\
\text { Pakistan including the } \\
\text { ISI and the armed } \\
\text { forces }\end{array}$ & \\
\hline $\mathrm{We}$ & reject & $\begin{array}{l}\text { emphatically } \\
\text { [circumstance: } \\
\text { quality] } \\
\text { such accusations } \\
\text { [verbiage] }\end{array}$ \\
\hline & has been explained & in the statements & all this [verbiage] \\
\hline & was ordered & the Air Force & $\begin{array}{l}\text { to scramble } \\
\text { [verbiage] }\end{array}$
\end{tabular}

Besides, verbal processes are involved in rejecting the notion of divide amongst the Pakistani nation and State Institutions as well as reject the apprehensions concerning Pakistan's relation with the US.

Lastly, relational identifying processes are also found in a relatively higher percentage in Gillani's address as compared to Obama's speech. Identifying processes in Gillani's speech are employed mainly to identify the stance of Pakistani nation and Pakistani forces, for instance, 
Table: 16

\begin{tabular}{l|l|l|l} 
Token & $\begin{array}{l}\text { Process: relational } \\
\text { identifying }\end{array}$ & Value & Others \\
\hline We & are & a proud nation & \\
\hline Our nation & is & resilient & $\begin{array}{l}\text { our people and our } \\
\text { State institutions }\end{array}$ \\
\hline Our real strength & is & $\begin{array}{l}\text { not the birth place of } \\
\text { Al Qaeda }\end{array}$ & \\
\hline Pakistan & is & $\begin{array}{l}\text { the war against } \\
\text { terrorism }\end{array}$ &
\end{tabular}

Another category of the relational identifying processes identify the enemy, for instance, Table: 17

\begin{tabular}{l|l|l|l} 
Token & $\begin{array}{l}\text { Process: } \text { relational } \\
\text { identifying }\end{array}$ & Value \\
\hline Osama bin Laden & was & $\begin{array}{l}\text { the most wanted } \\
\text { terrorist and enemy } \\
\text { number one of the } \\
\text { civilized world }\end{array}$ &
\end{tabular}

Besides these processes whose discussion is given above there a few minor process-types in Gillani's speech like the existential, behavioral and relational attributive processes.

\section{Discussion on Participant Roles Attributed to Enemy}

As Richardson says that language is social and constructs identity (Richardson, 2007) so now keeping in view this aspect the effort is put to trace the roles that have been attributed to the enemy i.e. Osama Bin Laden by the individual speakers i.e. Obama and Gillani. The focus is to investigate the different roles of actor, goal, senser, phenomenon, carrier, attribute, token, value.

First of all, Obama's speech is analyzed in order to explore the various participant roles that are given to Osama Bin Laden such as goal, carrier, token, sayer, phenomenon, and actor. The arguments will be illustrated by citing examples from both the speeches. The percentage of the major roles designated to Osama Bin Laden is given in the table below:

Table: a

\begin{tabular}{l|l|l|l|l|l|l|l}
$\begin{array}{l}\text { Participant } \\
\text { Role }\end{array}$ & Goal & Actor & Token & Carrier & Phenomenon & Sayer & Circumstance \\
\hline Percentage & $43.75 \%$ & $21.87 \%$ & $12.5 \%$ & $6.25 \%$ & $6.25 \%$ & $6.25 \%$ & $3.125 \%$
\end{tabular}

Thus, it is evident from the table (a) that the most dominant role in which the enemy is seen to be engaged in our data is 'goal' which implies that something happened to him, something was done to him as is evident that the address is delivered soon after an operation that's been performed in order to kill Osama Bin Laden (the enemy) as is also clear from the participant-role analysis.

With this we arrive at the participant roles that are given to the enemy in Gillani's speech. The percentage of the various participant roles stated to the enemy are listed below: 
Table: $b$

\begin{tabular}{c|c|c|c|c|c|c|c|c}
$\begin{array}{c}\text { Participant } \\
\text { Role }\end{array}$ & Goal & Actor & Circumstance & Token & Value & Receiver & Attribute & Verbiage \\
\hline Percentage & $41.17 \%$ & $26.4 \%$ & $8.82 \%$ & $5.88 \%$ & $5.88 \%$ & $5.88 \%$ & $2.94 \%$ & $2.94 \%$
\end{tabular}

The predominant role given to the enemy in Gillani's address is again 'goal' same as that of the Obama's address (see table (b)). It again implies that enemy is acted upon by outer agencies (see discussion under table 13). However, after goal the next predominant role given to enemy is that of 'actor' implying that the enemy is seen to be involved in actions which predominantly construe the negative proceedings like 'launched waves after waves of terrorists' attacks against innocent Pakistanis' and 'Al Qaeda and its affiliates carried out hundreds of suicide bombings in nearly every town and city of Pakistan and also targeted political leaders, State institutions, the ISI and the General Headquarters'. See the tables 5, 6, 7, 9 and 17 for similar descriptions of enemy by the speakers i.e. President Obama and Premier Gillani. Another astonishing fact is that the enemy is denied the role of 'sayer' and 'senser' in Gillani's speech. We aren't informed about enemy's sayings and thoughts directly. Most of the clauses representing enemy are the ones attributing qualities to the enemy, for instance, 'the anger and frustration of ordinary people over injustice, oppression and tyranny that he sought to harness to fuel the fire of terrorism in the world' or statements issued by others about the enemy, for instance, 'who was Osama Bin Laden and what did he personify', but the audience is not informed directly through the enemy's own point of view. In other words, enemy's voice is not materialized in the whole speech.

Lastly, when seen both the speeches in comparison to one another it becomes evident that in case of Obama's address the enemy is mainly addressed as Bin Laden or at the most as Osama Bin Laden (see table (b) above) but in the case of Gillani's address it is observed that in majority of the cases the enemy is being addressed in abstract notions of terrorism rather than addressing him directly. For the most part the enemy is being addressed through the larger category of Al-Qaeda, for instance, 'Al Qaeda and its affiliates', 'the war against terrorism', 'the Taliban regime', 'Al-Qaeda leaders and foot soldiers', 'AlQaeda members', 'the Al Qaeda chief along with other Al Qaeda operators'.

As this paper is engaged with a functionalist approach, functionalists assume that language is active (Richardson: 2007). Language is used to mean something and to do something and the 'meaning' and 'doing' are linked with the context of its usage. So, in order to completely interpret discourse we need to work out what the speaker or writer is doing through discourse, and how this 'doing' is related to wider interpersonal, institutional, socio-cultural, and material contexts (Cameron: 2001). When both the speeches are seen in the sociopolitical context the most significant difference arises from the fact that President Obama is addressing his nation directly while PM Gillani is addressing the nation through the parliament. The linguistic choices made by President Obama and Premier Gillani are highly significant in defining the narrative in political discourses. Speeches made both by President Obama and Prime Minister Gillani have certain linguistic choices that suit the need of their speeches. Obama and the US administration aimed to unite the American citizens under one banner hence the linguistic choices made by President Obama are emotional in nature and serve the purpose of rhetoric and united America (see table 4 above) Also, Obama several times appraised Pakistan Army and the ISI in his speech to serve the purpose of satisfying Pakistan as tension grew between the administrations of both the countries after the operation. Whereas, Prime Minister Gillani had to answer the Pakistani nation about the territorial sovereignty breached by USA and to the international community about the presence of Osama bin Laden in Pakistan. Therefore, Gillani's linguistic choices are found to be relatively defensive as it was the need of the hour to structure a narrative that would appease both the Pakistani nation by warning US concerning future strikes and to answer to the international community by referring to the efforts made by Pakistan to eliminate terrorists from the country (see tables $8,11,14,15$, and 16 for a fuller reference). As stated earlier, it can be formulated that Obama is addressing as a triumphant king who's announcing his victory while on the other hand Gillani's address is on an explanatory note explaining the charges leveled 
against Pakistani government and armed forces.

\section{Strategy to Gain Attention}

The sociologist Atkinson (1984) presented a concept of three-part list which appeals to be successful in invoking the attention of the audience. In a three-part list a statement is presented by a series of three specific concepts together.

In Obama's speech three-part list is evident. He uses this strategy 3 times in his speech.

1. 'And so we went to war against Al-Qaeda to protect our citizens, our friends, and our allies.'

2. 'We continued our broader efforts to disrupt, dismantle, and defeat his network.'

On the other hand Gilani has employed this strategy only once.

'Our friends can from this discourse fathom the depth of our sentiments, the aspirations of our people, the authentic spirit that guides and inspires them to seek equity, justice, security, peace, progress and prosperity.'

\section{Pronoun Choices}

Pronouns include three kinds of pronouns i.e. personal, possessive and reflexive. Personal pronouns constitute I, me, we, us, you, he, him, she, her, it, they, them. Possessive pronouns include my, mine, our, ours, your, yours, his, her, hers, its, their, theirs. Reflexive pronouns include himself, herself, themselves.

\section{Presentation of results: Pronoun choice}

Following table represents the different pronoun choices made by both the speakers i.e. Obama and Gillani. Results have been calculated according to choice of person in each case and as a proportion of total pronouns used overall.

Personal pronouns in proportion to total pronouns used

Table (i)

\begin{tabular}{l|l|l|l|l|l|l|l}
\multirow{2}{*}{ Names } & \multirow{2}{*}{ Total } & \multicolumn{2}{l}{ First Person } & \multicolumn{2}{l|}{ Second Person } & \multicolumn{2}{l}{ Third Person } \\
\cline { 3 - 8 } & & Number & $\%$ & Number & $\%$ & Number & $\%$ \\
\hline Gilani & 159 & 119 & 74.8 & 2 & 1.2 & 38 & 23.8 \\
\hline Obama & 143 & 109 & 76.2 & 3 & 2.0 & 30 & 20.9
\end{tabular}

Table (i) shows that both Gilani and Obama used total 159 and 143 pronouns respectively. Seeing the overall pronoun frequency does not suggest any remarkable differences. Interesting differences arise in terms of individual choices for first and third person pronouns. The choices for all persons are therefore examined in some detail in the following subsections.

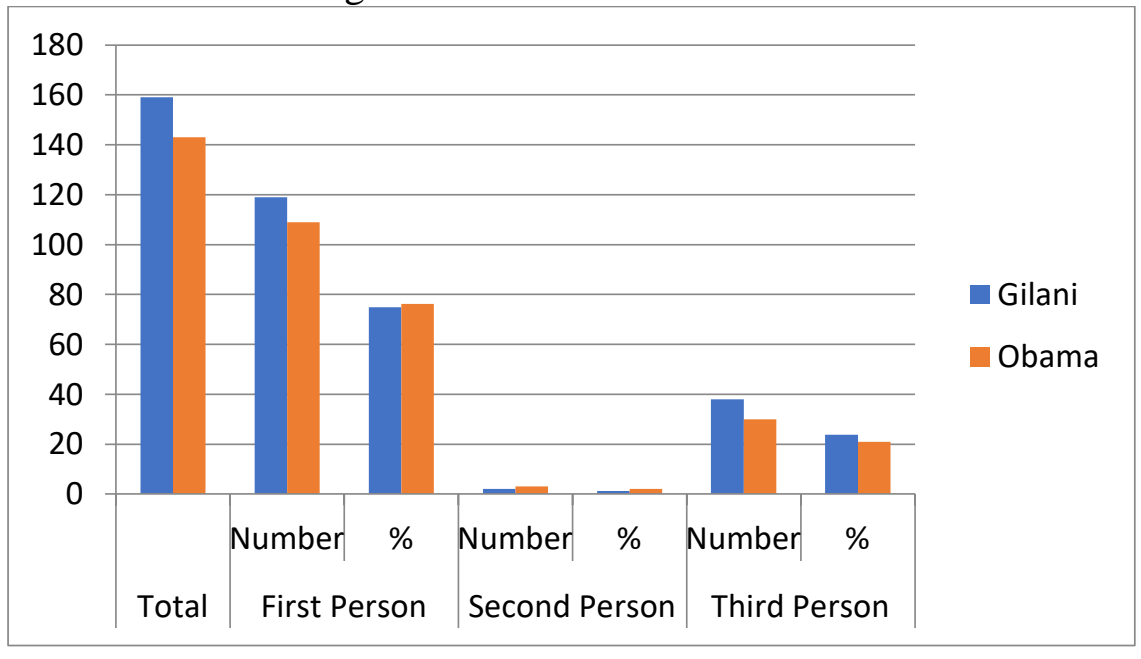




\section{First person pronouns:}

Following table presents the number of first person pronouns employed by both the speakers, further differentiating between singular and plural pronouns.

First person pronouns, singular vs. plural: numbers and proportions of total pronouns used

Table: (ii)

\begin{tabular}{l|l|l|l|l|l|l|l} 
Names & Total & \multicolumn{2}{|l|}{$\mathbf{1}^{\text {st }}$ Person Pronouns } & Singular & \multicolumn{2}{l}{ Plural } \\
\cline { 3 - 8 } & Pronouns & Number & $\%$ & Number & $\%$ & Number & $\%$ \\
\hline Gilani & 159 & 119 & 74.8 & 19 & 11.9 & 100 & 62.8 \\
\hline Obama & 143 & 109 & 76.2 & 15 & 10.4 & 94 & 65.7
\end{tabular}

It shows that Gilani and Obama used approximately the same number of first person pronouns in the speeches i.e. $119(74.8 \%)$ and 109 (76.2\%) respectively. There is just difference of 10 in first person pronouns used by both the speakers. Majority of these are in fact first person plural pronouns - variants of we.

Use of We: The first person plural 'we' is very ambiguous in terms of political meaning as it can mean either inclusive or exclusive of the addressee.

Gilani has made 35 uses of 'we' whereas Obama has used 'we' 41 times.

In Gilani's speech, his use of 'we' is mainly inclusive of the addressee which means either we the Nation or we the National Assembly. In some of his statements, Gilani meant we, 'The Nation' by using we:

'We are a proud nation ... We opened our homes and our hearts to those...'

Then his use of 'we' at some places implies 'We' the National Assembly:

'We did not invite Osama bin Laden to Pakistan o even to Afghanistan ... We did not invite Al-Qaeda to Pakistan.'

In Obama's speech the use of 'we' refers to 'Democratic Party' ,'the Nation ','The Government.' He uses 'we' as Democratic Party:

'And yet we know that the worst images are those that were unseen to the world'.

He uses 'we' as the nation:

'We offered our neighbors a hand and we offered the wounded our blood.'

Use of I: In Obama's speech Obama used the first person singular pronoun 'I' and its variants 12 times as compared to Gilani who used 17 times. In Obama's speech the uses of I are openly personal reference as he says 'I can report', 'I directed Leona Panetta ', 'I was briefed' ,'I met repeatedly ,'I determined, 'I called', ' I as Commander-in-Chief', 'I know' and twice uses 'I've made clear'. By making use of these pronoun choices Obama is presenting himself as he did all that which is described above .He made no use of collocations like 'you and I' in other words he did not involve the audience with him in any of the sentence in his speech and completely focused on himself. Then he used the word 'me', another first person singular pronoun, at two places in his speech. In the first place he says:

'These efforts weigh on me every time I, as Commander-in-Chief, have to sign a letter to a family that has lost a loved one, or look into the eyes of a service member who's been gravely wounded.",

Here Obama is directing himself that as he is the Commander-in-Chief, every time it becomes his duty to write a letter of sympathy to the people who have to suffer the outcome of war and who have to suffer the loss of their loved ones. In this statement Obama is presenting himself as fulfilling all his duties that are the demand of his position. It is Obama who performs this act of sympathy with the people every time after war. In other words he is telling that he is the source that performs the duty to console the sufferers.

At another occasion, Obama says

"Finally, let me say to the families who lost loved ones on 9/11 that we have never forgotten your loss, nor wavered in our commitment to see that we do whatever it takes to prevent another attack on our shores." 
In this statement once again Obama is showing sympathy towards the sufferers by saying that we have not forgotten your loss and then he is promising that we will do whatever we can in order to prevent any other attack. His tone is sympathizing and promising.

On the other hand, Gilani has used I at various places as 'I wish', 'I had extensive consultations', 'I talk of a bygone era', 'I would like', 'I must say,' I was invited', 'I would like to inform you', 'I would like to conclude', 'I have directed', I look forward'.

In both the speeches, both Obama and Gilani are making a clear representation of themselves to their audience including the present audience, their nation and to the whole world.

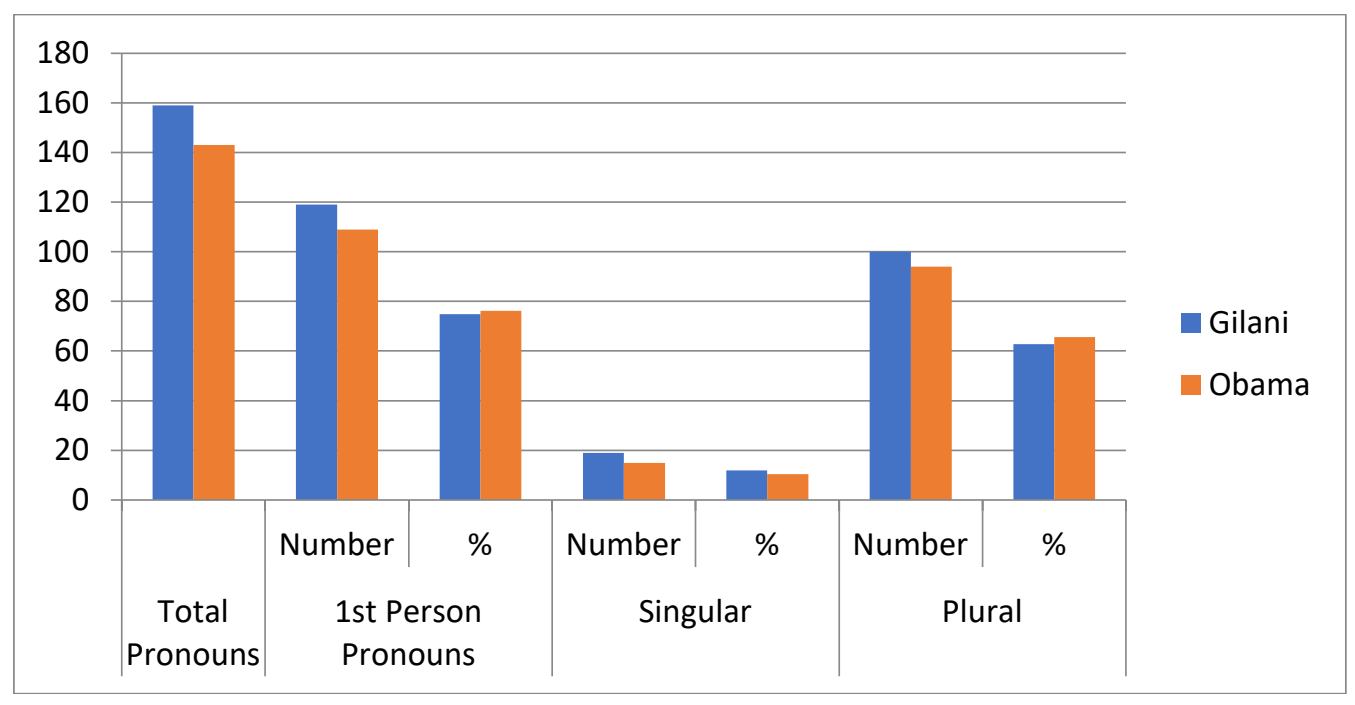

In the speeches the use of first person singular pronoun Gilani's speech is 119 as compared to Obama's speech which is 109 .

\section{Second person pronoun}

Table: (iii)

\begin{tabular}{l|l|l|l} 
Names & Total Pronouns & Total Second Person Pronouns & Percentage \\
\hline Gilani & 159 & 2 & 1.2 \\
\hline Obama & 143 & 3 & 2.0
\end{tabular}

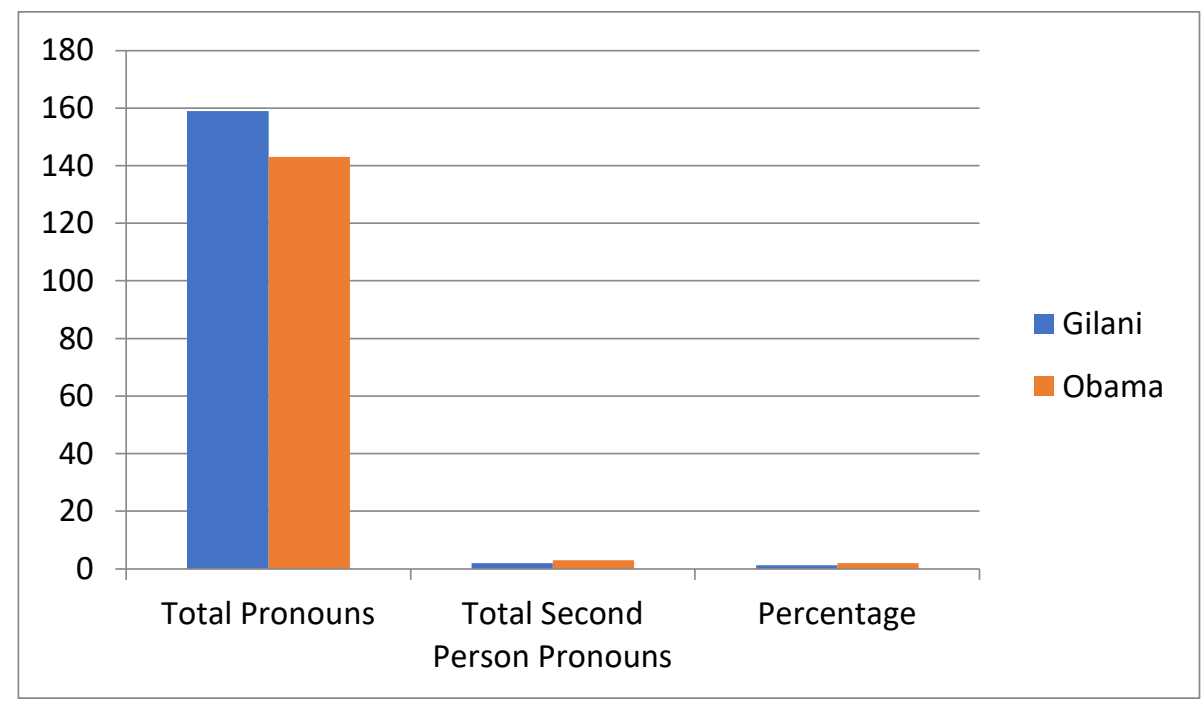


Second person pronoun represents only a very small proportion of total pronoun use by both the speakers only twice by Gillani and thrice by Obama (1.2 percent and 2.0 percent respectively). Neither speaker therefore, makes explicit reference to a potential addressee or group of addressees who are - distinct and separate from the speaker. However some of their individual uses may be noteworthy since the use of 'you' can in certain circumstances allows degree of confusion which has exploitative potential (Fairclough, 2001:149, for example, interprets Thatcher' use of you as an indefinite pronoun, referring to people in general, as a claim of solidarity with the people).

Gilani has employed the pronoun you twice in his whole speech. In both places, Gilani is addressing the delegates or the people in the hall.

While Obama has made use of the second person 'you' twice \& 'your' only once.

1. 'Thank you. May God bless you'.

Here Obama is trying to show sympathy towards the people who suffered loss because of the attack and he is acknowledging that people have really suffered that's why he uses the word 'your loss'.

Third Person Pronoun

Following table presents the number of third person pronouns used by both the speakers, further differentiating between singular and plural pronouns.

Table: (iv)

\begin{tabular}{|c|c|c|c|c|c|c|c|}
\hline \multirow[t]{2}{*}{ Names } & \multirow[t]{2}{*}{$\begin{array}{l}\text { Total } \\
\text { Pronouns }\end{array}$} & \multicolumn{2}{|c|}{$\begin{array}{ll}3^{\text {rd }} & \text { Person } \\
\text { Pronouns } & \end{array}$} & \multicolumn{2}{|c|}{ Singular } & \multicolumn{2}{|l|}{ Plural } \\
\hline & & Number & $\%$ & Number & $\%$ & Number & $\%$ \\
\hline Gilani & 159 & 38 & 23.8 & 28 & 17.6 & 10 & 6.2 \\
\hline Obama & 143 & 31 & 21.6 & 17 & 11.8 & 14 & 9.7 \\
\hline
\end{tabular}

Gilani has used more repetitively the third person pronouns which is $38(23.8 \%)$ as compared to Obama's $31(21.6 \%)$ uses. Gilani preferred the use of singular pronouns (28 I .e 17.6\%) while Obama made more use of (14 I .e 9.7\%) third person plural pronouns.

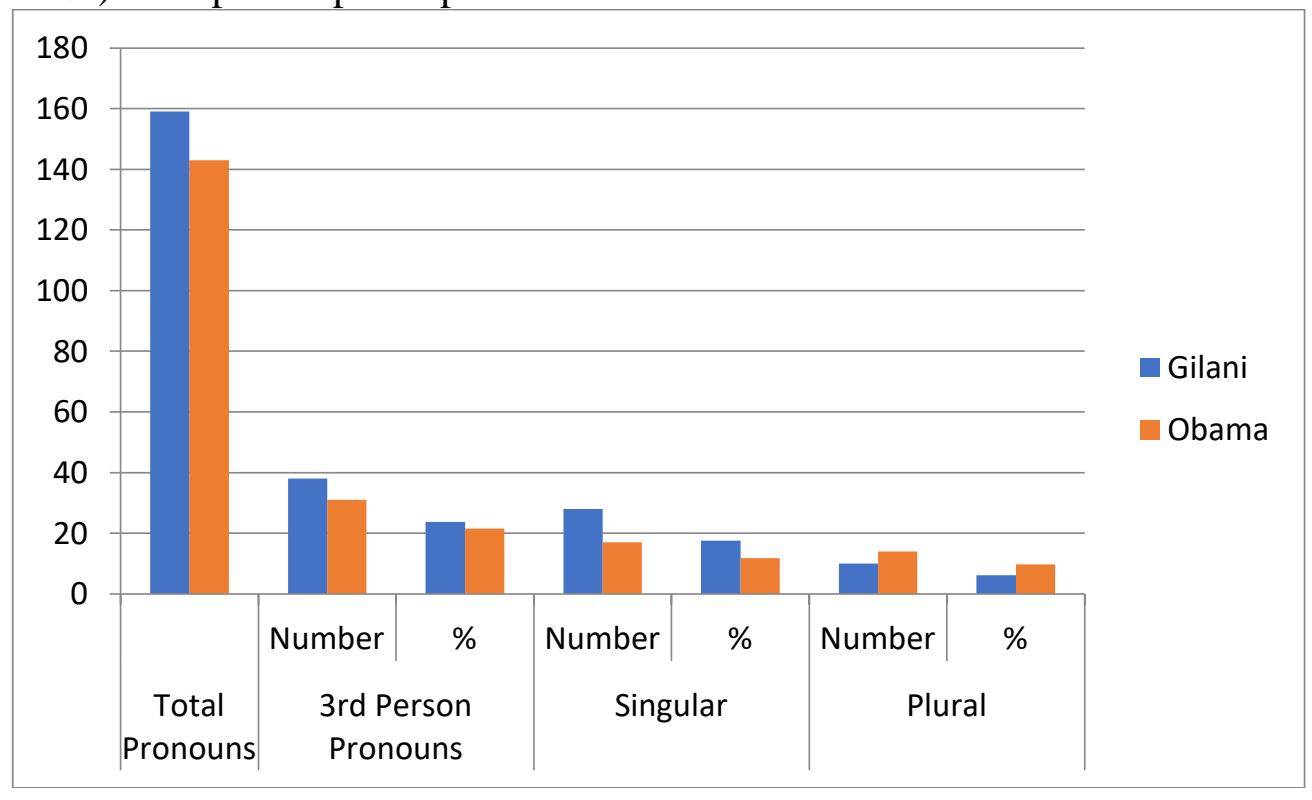

\section{Singular VS Plural:}

Following table compares the use of singular and plural pronouns (all persons) by both the speakers in proportion to their total pronoun use.

Table shows that both Obama and Gillani prefer to use plural pronouns of all types. 
Table: (v)

\begin{tabular}{l|l|l|l|l|l} 
Names & \multirow{2}{*}{$\begin{array}{l}\text { Total } \\
\text { Pronouns }\end{array}$} & \multicolumn{2}{|l|}{$\begin{array}{l}\text { Total } \\
\text { Pronouns }\end{array}$} & Singular & \multicolumn{2}{l}{$\begin{array}{l}\text { Total } \\
\text { Pronouns }\end{array}$} \\
\cline { 3 - 6 } & & Number & $\%$ & Number & $\%$ \\
\hline Gilani & 159 & 48 & 30.1 & 111 & 69.8 \\
\hline Obama & 143 & 32 & 22.3 & 112 & 78.3
\end{tabular}

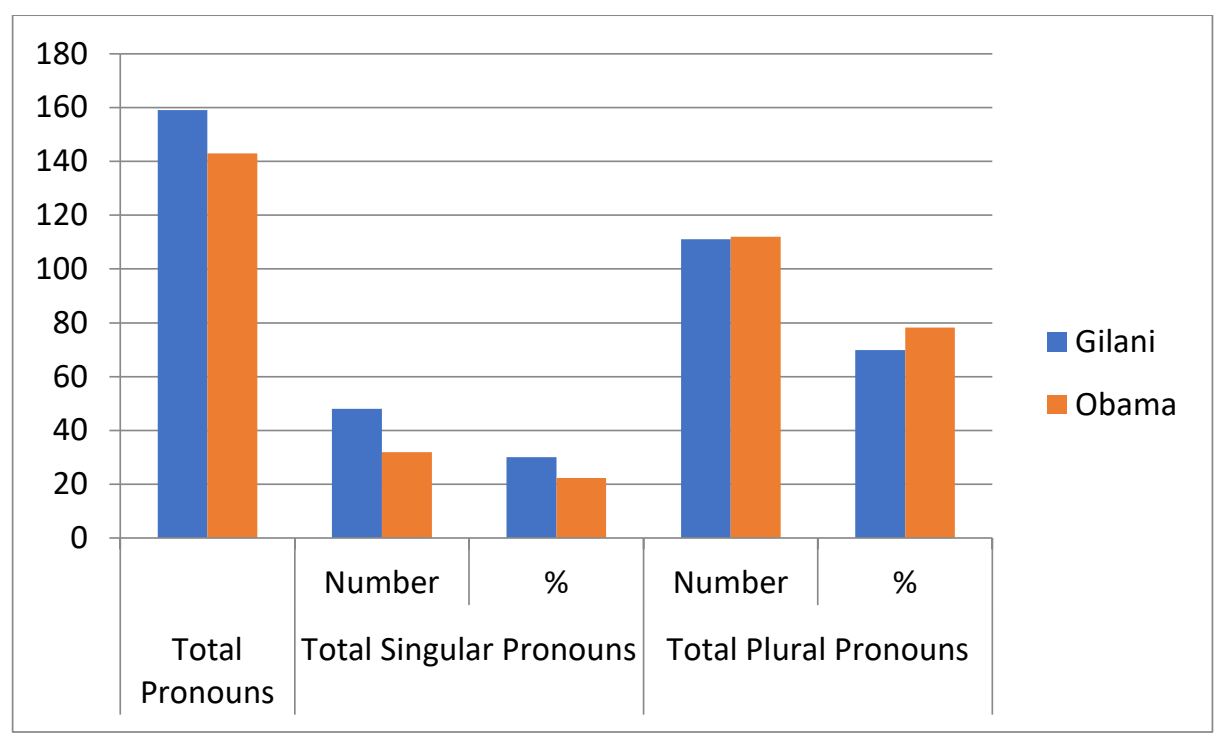

Obama used $78.3 \%$ plural pronouns while Gilani used $69.8 \%$ and Obama used $22.3 \%$ singular pronouns while Gilani used 30.1\%. Comparatively, Gilani used greater number of singular pronouns as compared to Obama and Obama used greater number of plural pronouns as compared to Gilani.

\section{Lexical Repetition}

All lexical repetitions identified in the speeches were calculated for each item and each speaker respectively. Each total was then calculated in proportion to the total number of words in each speech.

Table: (vi)

\section{Gillani}

\section{Obama}

\begin{tabular}{|c|c|c|c|c|c|}
\hline Total Words = 2946 & $\begin{array}{l}\text { Number } \\
\text { times used }\end{array}$ & $\begin{array}{l}\text { Percentage of } \\
\text { Total Words }\end{array}$ & Total Words $=1367$ & $\begin{array}{l}\text { Number } \\
\text { Times Used }\end{array}$ & $\begin{array}{l}\text { Percentage of } \\
\text { Words Used }\end{array}$ \\
\hline Defeating & 1 & 0.03 & Defeat & 2 & 0.14 \\
\hline Peace & 2 & 0.06 & Peace & 1 & 0.07 \\
\hline Security & 9 & 0.3 & Courage & 2 & 0.14 \\
\hline Pakistan & 39 & 1.32 & Islam & 2 & 0.14 \\
\hline Pakistani & 1 & 0.03 & Security & 2 & 0.14 \\
\hline Targeted & 1 & 0.03 & Pakistan & 9 & 0.65 \\
\hline Death & 4 & 0.135 & Determined & 1 & 0.07 \\
\hline Terror & 4 & 0.13 & Determination & 1 & 0.07 \\
\hline Anti-terror & 3 & 0.1 & Targeted & 1 & 0.07 \\
\hline Terrorist & 1 & 0.03 & Against & 9 & 0.65 \\
\hline Terrorists & 2 & 0.06 & Leader & 3 & 0.21 \\
\hline Terrorism & 8 & 0.02 & Friends & 4 & 0.29 \\
\hline Anti-terrorism & 1 & 0.03 & Death & 2 & 0.14 \\
\hline Counterterrorism & 1 & 0.03 & Effort & 3 & 0.21 \\
\hline Slaughtered & 0 & - & Efforts & 2 & 0.14 \\
\hline Hiding & 1 & 0.03 & Slaughtered & 1 & 0.07 \\
\hline Hide & 1 & 0.03 & Counterterrorism & 3 & 0.21 \\
\hline Sacrifice & 1 & 0.03 & Declared & 2 & 0.14 \\
\hline Sacrifices & 1 & 0.03 & Sacrifice & 1 & 0.07 \\
\hline Power & 1 & 0.03 & Sacrifices & 1 & 0.07 \\
\hline Powers & 3 & 0.1 & Service & 2 & 0.14 \\
\hline Affiliates & 1 & 0.03 & Struggle & 2 & 0.14 \\
\hline Al-Qaeda & 17 & 0.5 & Lost & 3 & 0.21 \\
\hline
\end{tabular}




\begin{tabular}{|c|c|c|c|c|c|}
\hline Operation & 6 & 0.2 & Love & 1 & 0.07 \\
\hline Operations & 2 & 0.06 & Terror & 1 & 0.07 \\
\hline Justice & 2 & 0.06 & Countless & 1 & 0.07 \\
\hline War & 5 & 0.16 & Intelligence & 3 & 0.21 \\
\hline Innocent & 1 & 0.03 & Work & 0 & - \\
\hline Attack & 1 & 0.03 & Men & 2 & 0.14 \\
\hline Attacks & 2 & 0.06 & Women & 1 & 0.07 \\
\hline Defence & 3 & 0.1 & Children & 2 & 0.14 \\
\hline Violation & 2 & 0.06 & Serve & 1 & 0.07 \\
\hline Reconciliation & 1 & 0.03 & Values & 2 & 0.14 \\
\hline Honour & 2 & 0.06 & Liberty & 1 & 0.07 \\
\hline Dignity & 4 & 0.13 & Unity & 1 & 0.07 \\
\hline Islam & 2 & 0.06 & United & 2 & 0.14 \\
\hline Culture & 1 & 0.03 & Al-Qaeda & 12 & 0.08 \\
\hline Freedom & 1 & 0.03 & Kill & 1 & 0.07 \\
\hline Equality & 2 & 0.06 & Killed & 3 & 0.21 \\
\hline Humanity & 1 & 0.03 & Killing & 2 & 0.14 \\
\hline Harmony & 1 & 0.03 & Affiliates & 2 & 0.14 \\
\hline Brotherhood & 1 & 0.03 & Community & 2 & 0.14 \\
\hline Victory & 1 & 0.03 & & & \\
\hline Oppression & 1 & 0.03 & & & \\
\hline Tyranny & 1 & 0.03 & & & \\
\hline Sovereignty & 3 & 0.1 & & & \\
\hline Lost & 2 & 0.06 & & & \\
\hline Love & 0 & - & & & \\
\hline Wounded & 0 & - & & & \\
\hline Unity & 0 & - & & & \\
\hline Men & 0 & 0.03 & & & \\
\hline Women & 1 & 0.03 & & & \\
\hline Children & 0 & - & & & \\
\hline
\end{tabular}

Gilani has employed more repetitions as compared to Obama in his speech. Gilani used 115 while Obama used 99 repetitions. Gilani has used the words like 'Pakistan', 'Al-Qaeda' and 'Security' 39, 17 and 9 times respectively while Obama has used the words like 'Al-Qaeda', 'Pakistan' and 'Against' 17, 9 and 9 times respectively. Gilani has used terrorism related words 20 times in his speech which includes 'terror', 'terrorist', 'terrorism', 'counterterrorism', 'anti-terrorism' while Obama used such words only 4 times. Gilani uses 'Security' 9 times while Obama only twice. The use of the word 'lost' in Obama's speech is not found in Gilani's speech. Gilani has used the word 'war' 5 times. The only word that is seen in the same proportion in both the speeches is 'Islam' which is used by both Obama and Gillani twice. The word 'Slaughtered' is used by Obama but not used by Gilani in his speech. The word 'peace' is used just once by Obama while Gilani has used it twice. 'Unity' and 'united' are used 1 and 2 times respectively by Obama which are missing from Gilani's speech. The more a word is repeated, more a word is emphasized. All the above mentioned words which are repeated are showing their emphasis by the respective speakers.

This section has examined the language of political speeches paying attention to the choice of personal pronouns and the extent and the type of lexical repetition has shown that how a close examination of the patterning of particular linguistic choices can provide evidence of their notable emphasis within the political programs and their ideology.

\section{Conclusion}

In a nutshell, it can be stated that the use of language is never neutral. Speakers and writers organize their language in order to promote specific world-view. The users of language tend to construct reality corresponding to their own vested interests, ideological and political functions (Kuo \& Nakamura: 2005). The percentage of the process-types shows material process as the dominant type in both the speeches of Obama and Gillani. This result is justified to the extent that the speeches are delivered after the killing of Osama Bin Laden which itself involves a physical action. Moving to the participant roles it is observed that the enemy is portrayed in the dynamic roles of goal, actor, carrier, phenomenon, circumstance. Halliday and Matthiessen (1999), state that 'experience is the reality that we construe for ourselves by means of language'. So, the transitivity choices made by the speakers in their respective speeches is 
indicating the peculiar world-view espoused by the leading members of America and Pakistan. The results prove that language is a tool in the hands of the powerful who organize their message to convince the audience of their required aims and objectives especially when the topic concentrates on conflicting issues. The most significant fact from our analysis is that Obama has presented his actions as necessary and a result of what was forced on the American nation and has organized his rhetoric to promote the American unity while Gillani's whole address seems to be much more elongated, defined by the abstractness in contrast to Obama's address which is defined by the clarity and precision of the subject.

\section{References}

Atkinson, J. M. (1984). Our masters' voices: The language and body language of politics. London: Methuen.

Butt, D. G., Lukin, A., \& Matthiessen, C. M. (2004). Grammar-The First Covert Operation of War. Discourse \& Society.

Caffarel, A., \& Rechniewski, E. (2009). A systemic functional approach to analyzing and interpreting ideology: an illustration from French editorials. Revista Alicantina de Estudios Ingleses, (22), 27-43.

Cameron, D. (2001). Working with spoken discourse. London: SAGE.

Chomsky, N. (1992). Excerpts from Manufacturing Consent Noam Chomsky interviewed by various interviewers. Interview.

Durān, J. (2008). The Analysis of Political Discourse Applied to Bush's and Kerry's Speeches. Systemic Functional Linguistic in Use. 29(1): 267-282.

Erikson, R. S., \& Tedin, K. L. (2003). American public opinion: Its origins, content, and impact. New York: Longman.

Fairclough, N. (1989). Language and power. London: Longman.

Fairclough, N. (1992). Discourse and Social Change, London: Polity Press.

Fairclough, N. (1995). Critical discourse analysis. The critical study of language. Language in social life series. London: Longman.

Fairclough, N. (2000). Discourse, Social Theory, and social research: The discourse of welfare reform. Journal of Sociolinguistics, 4(2): 163-195.

Fairclough, N. (2001). Language and power. Harlow, Eng: Longman.

Firth, J.R. (1957). Papers in Linguistics 1934-1951 (1957) London: Oxford University Press.

Halliday, M. A.K, \& Matthiessen, C. M. (1999). Construing Experience through Meaning: A Languagebased Approach to Cognition. (OLS). London and New York: Cassel.

Halliday, M. A., \& Matthiessen, C. M. (2004). An introduction to functional grammar. London: Arnold.

Hasan, R. (1985). Linguistics, Language and Verbal Art. Melbourne: Deakin University Press. Reissued 1989, Oxford University Press.

Hasan, R. (1996). Ways of Saying, Ways of Meaning. Selected Papers of Ruqaiya Hasan. Edited by Carmel Cloran, David Butt and Geoff Williams. Cassell.

Horváth J. (2011) Critical discourse analysis of Obama's political discourse. Retrieved from http://www.pulib.sk/elpub2/FF/Ferencik2/pdf_doc/6.pdf

Kuo, S., \& Nakamura, M. (2005). Translation or transformation? A case study of language and ideology in the Taiwanese press. Discourse \& Society.

Pelinka, A. (2007). Language as a political category: The viewpoint of political science. Journal of Language and Politics. 2007; 6(1):129-43.

$\mathrm{Pu}$, C. (2007). Discourse Analysis of President Bush's Speech at Tsinghua University, China. Intercultural Communication Studies, XVI(1): 205-216.

Richardson, J. E. (2007) Analysing Newspapers: An Approach from Critical Discourse Analysis

Hunston, S. (2010). Corpus approaches to evaluation: Phraseology and evaluative language. Routledge.

Hunston, S. (2004). Counting the uncountable: Problems of identifying evaluation in a text and in a corpus. Corpora and Discourse, 9, 157-188.

Tehseem, T. (2013) Transitivity in Pakistani Journalistic Discourse: A Linguistic Analysis of Ideology, ELF Annual Research Journal 15 (2013) 19-38. 
Thompson, G. (2004) Introducing Functional Grammar (2nd edition) London: Arnold.

Thompson, G. (2008). From process to pattern: Methodological considerations in analysing transitivity in text. In Carys Jones \& Eija Ventola (eds.) New Developments in the Study of Ideational Meaning. From Language to Multimodality, 17-33. London: Equinox.

van Dijk, T.A. (1993). Principles of critical discourse analysis. Discourse \& Society. 4(2): 249-283. van Dijk, T.A. (1997). What is political discourse analysis? Belgian Journal of Linguistics. 11(1): 11-52. Weiss, G., \& Wodak, R. (2007). Critical discourse analysis. New York: Palgrave Macmillan.

Wodak, R. \& Chilton, P. (2005). A new agenda in (critical) discourse analysis: theory, methodology and interdisciplinarity. Vol. 13. John Benjamins Publishing.

Wodak, R. \& Meyer, M. (2009). Methods for critical discourse analysis. Sage. 